haitiana che scrivono in francese. Il fatto è che nella formula di Elio Costa - molto suggestiva, ripeto - il "we", il noi, i docenti sembrano piazzarsi in un al di là irrevocabile, da non scomodare. Ma i professori non sono meno "empirici" degli studenti. Per insegnare bene occorre interrogarsi non semplicemente sul "where" degli alunni ma anche sul nostro. Se vogliamo recuperare l'umanesimo o qualsiasi altra componente della cultura italiana per inserirci nel discorso critico nordamericano, dobbiamo partire dai dettami di quel discorso, e non procedere antagonisticamente, calzando il coturno, riproponendoci nei panni di grandi civilizzatori assediati da orde di barbari che non hanno capito la lezione, immaginandoci a guisa di discendenti di Leonardo da Vinci e di Cristoforo Colombo in un ingrato fin de siècle, a cui la cultura indigena, nordamericana non offre - e non potrà mai offrire - nessun nutrimento. Dobbiamo diventare capaci di ammettere - quelli di noi che sono di origine italiana e che risiedono in questo continente che se culturalmente non siamo né qui né lì, la nostra vita di cittadini la viviamo qui. Dobbiamo - per riassumere velocemente - imparare a parlare di noi stessi. Solo così riusciremo a dialogare con i nostri colleghi italiani e nordamericani di altra origine, e non essere sempre e solo bravi uditori, pazienti e passivi destinatari di strumenti che sono per il nostro mestiere e per la nostra identità intellettuale condizione necessaria ma non sufficiente. Utilissimo per aver tolto i veli alla 'nostra' crisi, alle 'nostre' contraddizioni, il libro di Picchione e Pietropaolo merita un secondo o un terzo volume.

\title{
FRANCESCO LORIGGIO
}

Carleton University

Anthony Mollica, Julie Ashcroft, Anne-Marie Finger e Angelo Chiuchiù. Una immagine vale . . 1000 parole . . . . Attività creative per lo sviluppo delle abilità linguistiche. (Guida per l'insegnante) Libro 1 (pagine staccabili da fotocopiare). Welland: Editions Soleil Publishing Inc., 1992. Pp. xiii, 60.

Anthony Mollica. A Picture is Worth . . 1000 Words: Creative Activities for the Language Classroom. Book 1 (line master for reproduction). Welland: Éditions Soleil Publishing Inc., 1992. Pp. xii, 120.

Anthony Mollica, Julie Ashcroft, Anne-Marie Finger e Angelo Chiuchiù. Una immagine vale . . 1000 parole . . . A Attività creative per lo sviluppo delle abilità linguistiche. (Guida per l'insegnante) Libro 2 (pagine staccabili da fotocopiare). Welland: Editions Soleil Publishing Inc., 1992. Pp. xiii, 60.

Anthony Mollica. A Picture is Worth . . 1000 Words: Creative Activities for the Language Classroom. Book 2 (line master for reproduction). Welland: Editions Soleil Publishing Inc., 1992. Pp. xii, 120.

In recent years the trend in the second language classroom has been that of encouraging spontaneous conversation and developing communicative competence in the target language. It is to this end that A Picture is Worth ... 1000 Words . . has been created.

The difficulty that instructors often face in the language class is the reluctance and unwillingness of students to converse in the target language. This problem is coupled with the fact that the stimulus presented is often too difficult and requires a linguistic ability and knowledge that the learner may not yet posses. Generally topics of current issues are chosen as items of conversation which tend to be better suited for advanced 
stages of instruction and present quite an obstacle during the early stages of language learning. The objective then is to create activities or choose topics for conversation which lie within the learners' linguistic competence. In the preface to the collection of photographs Mollica and the other authors highlight the importance of capitalizing on visual imagery to augment learning. They write: "The use of visual imagery in learning, as psycholinguists often point out, is crucial to recall mechanisms and development of eidetic memory, and this, of course, is beneficial to language learning" (v).

Of the two volumes, a Teacher's Guide and a volume containing photographs, the Teacher's Guide is available in Italian, English, French, German, Portuguese and Spanish and contains exercises designed for each individual photograph. The book of photographs contains 60 high-quality, easily reproducible, black-and-white photographs in two sizes - a full size photograph (approximately 8"x10") and a smaller 3"x5" of the same photograph on the reverse side of the page. The authors suggest that the larger photo be used for group activities while the smaller photo is suitable for individual work. The space provided on the page displaying the smaller photo can be used for creative writing tasks or for collecting lexical items that pertain to the photograph. It is important to note that the teacher is given reproduction privileges with purchase of the books so that photocopies may be made for use in the language class.

The book is composed of a collection of photographs selected from both Canadian and American local daily and weekly newspapers. The themes of the photographs include depiction of real life conditions, community events and social situations. It is the North American content of the photographs which makes this book unique and innovative. No matter what language is being taught the photographs are culturally relevant to the language leamer.

In the Teacher's Guide a brief yet comprehensive introduction provides the instructor with a theoretical background and explanation of the importance of appropriate communicative activities in the $\mathrm{L} 2$ class. This discussion is followed by a practical guide for the maximum utilization of the material. Included also are suggestions and ideas for creative activities ranging from writing radio or television announcements to sequencing photos to create a story board, to memory games.

As is the case with all good guides, the focus of this book is to provide suggestions and ideas to optimize learning in an entertaining and pedagogically sound fashion, and as such it must be seen as a resource manual. The language instructor may use the exercises in the L2 classroom but must never forget that these exercises may be augmented through his/her own creativity. Since the authors of this book recognize the importance of the teacher and his/her contribution to classroom activities the bottom of each page leaves space in which the instructor may include additional activities which $\mathrm{s} / \mathrm{he}$ has designed. An innovative aspect of the book is that it addresses the student's cultural understanding and reconciles this knowledge with the student's "budding" linguistic knowledge.

There are ten to fifteen activities per photograph ranging from listing vocabulary words and expressions to creating a caption for the photograph to discussing cultural issues. The activities provide the trigger for a description and/or discussion of the learner's community in the target language. These exercises may consist of a description of an event which is typical of North America, a discussion of current issues in the learner's community, or a reflection on sentiments underlying the photos and the students' own feelings on the subject. 
Since the activities do not follow any hierarchy the teacher may select those questions which best suit the level of competence of his/her students or the ones which best reflect alternative goals set by the instructor (e.g. those that coincide with a unit being studied). The activities listed in the Teacher's Guide can be selected or adapted for beginner, intermediate and advanced levels and are equally effective in both child and adult L2 classes. According to the authors the questions have been designed to stimulate: A) visual understanding - the student is asked to describe what $\mathrm{s} / \mathrm{he}$ sees; B) personal interpretation - the student is asked to express his/her opinion on the subject matter of the photograph; and C) creativity - this stage stimulates the imagination and inventiveness. These goals are intended to coincide with the three levels of instruction: beginner, intermediate and advanced. All three stages can be fused together depending on the abilities and level of the language learners.

The highly interesting ideas and suggestions for classroom activities and discussions presented in the Teacher's Guide can be used both to improve communicative competence and to enhance writing skills and are perhaps the most valuable aspect of this book. They can be easily adapted to other visual material or items for conversation. Indeed the flexibility and wide range of the activities make the book easily adapted to all levels of $\mathrm{L} 2$ learning. The collection is unique in that the volume containing the photos may be used independently of the Teacher's Guide and the activities can be translated into those languages for which a guide does not exist. Thus, it is true, a picture is worth a thousand words, in as many languages.

\section{CARMELA COLELLA}

University of Toronto 